Александрова Наталья Игоревна

студентка

ФГБОУ ВО «Липецкий государственный технический университет» г. Липецк, Липецкая область

DOI $10.21661 / r-114435$

\title{
ПРОЗРАЧНЫЙ БЕТОН
}

Аннотация: в данной работе исследователем описан такой новый строительный материал, как прозрачный бетон. В статье объясняется прочесс изготовления прозрачного бетона, а также представлены свойства рассматриваемого материала.

Ключевые слова: прозрачный бетон, литракон, оптоволокно, стекловолокно.

Бетон в строительстве всегда занимал важное место. Единственным недостатком этого материала является его внешний вид. Эта проблема легко решается с помощью различных декоративных и облицовочных материалов.

В 2001 году появился инновационный светопропускающий материал - прозрачный бетон. Пропускание света обеспечивается за счет оптоволокна, который входит в состав прозрачного бетона или литракона.

Прозрачность материала условна. Через него можно видеть контур объекта, но для этого необходима подсветка с обратной стороны.
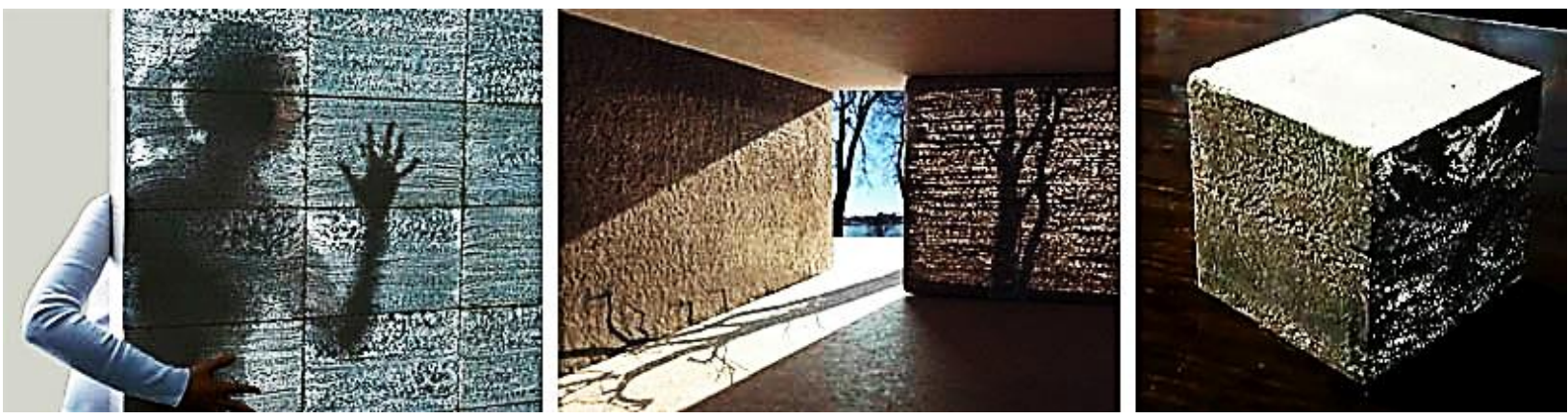

Рис. 1. Прозрачный бетон (литракон) 
Сырьем служит цемент, песок с модулем крупности 2-3, стекловолокно диаметром от 0,5 до 2,5 мм и модифицирующие добавки.

Процесс изготовления прозрачного бетона представляет собой послойную укладку стекловолоконных нитей и мелкозернистой бетонной смеси. После того как материал набирает необходимую прочность его шлифуют и полируют. Это делают для того, чтобы получить оптимальные светопропускающие свойства и предать материалу декоративный эффект. Соотношение стекловолокна и бетона зависит от необходимой прозрачности изготовляемых элементов. Объем стекловолокна составляет 4-5\%.

Готовая продукция абсолютно безопасна для человека. Прозрачный бетон имеет те же свойства, что и обычный:

- прочность: на сжатие в пределах 20-35 МПа, на растяжение при изгибе не менее 2;

- плотность - 2300 кг/см3;

- теплопроводность - 2,1 Вт/(м·К);

- морозостойкость до 75 циклов;

- марка водопроницаемости: W4-W8;

- водопоглощение: не более 6\%;

- звукоизоляция - 46 дБ.

Блоки прозрачного бетона укладываются на цементный или известковый раствор и могут склеиваться составами из эпоксидных смол и кварцевой крошки. Такая кладка подходит для устройства несущих стен, так как соответствует строительным и пожарным нормам. Так же для крепежа используют анкерные болты и рамочные конструкции.

Производство предусматривает изготовление блоков белого, черного, серого цвета, с зеркальным блеском и матовые, изогнутой формы и прямоугольные для соответствующих нужд потребителя.

Материал днем пропускает естественный свет, ночью - искусственный, не горит, не боится солнечных лучей. Литракол на данное время является эксклюзивным и дорогостоящим материалом. Для того чтобы снизить себестоимость 
продукции стекловолокно заменяется на пластиковое оптоволокно или пластичную смолу.

Чаще всего литракон используется в качестве элементов декора и дизайна: умывальников, фонтанов, барных стоек, столешниц, скамеек, лестниц, внутренних перегородок, фасадов зданий. Применение прозрачного бетона имеет большое будущее при организации наружного светового оформления на городских улицах. Города станут светлее и прозрачнее.
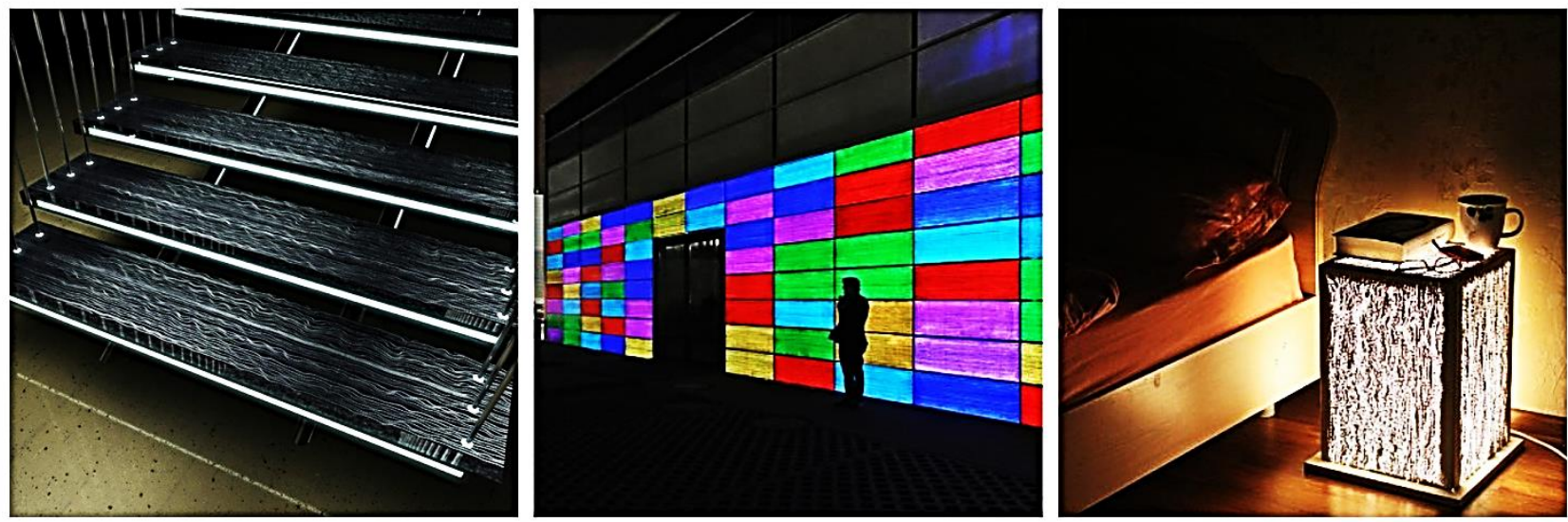

Рис. 2. Изделия из прозрачного бетона

В настоящее время прозрачный бетон нашел широкое распространение в ряде таких стран как Америке, Японии, Швейцарии, но России из-за большой стоимость материал используется редко.

Анализируя выше сказанное, можно сделать вывод, что в строительстве появился уникальный материал, не имеющий в своем роде аналогов. Этот материал позволит осуществить многие задумки, в результате которых мы сможем увидеть светящиеся дома, театры и другие постройки которые будут привлекать своей красотой и блеском, что в свою очередь выведет архитектуру на новый уровень и даст развитие новым архитектурным свершениям.

\section{Список литературы}

1. Прозрачный бетон: технология, сферы применения и особенности [Электронный ресурс].- Режим доступа: http://stroitel5.ru/chto-takoe-prozrachnyjjbeton-i-chto-neobkhodimo-dlya-ego-proizvodstva.html 
2. Прозрачный бетон: характеристики, технология производства, изготовление своими руками [Электронный ресурс].- Режим доступа: http://stroitellist.ru/beton/svetopropuskayushhie-kompozitnye-strojmaterialy-i-prozrachnyjbeton.html

3. Что такое прозрачный бетон [Электронный ресурс]. - Режим доступа: http://stroy-masterden.ru/chto-takoe-prozrachnyij-beton.html 